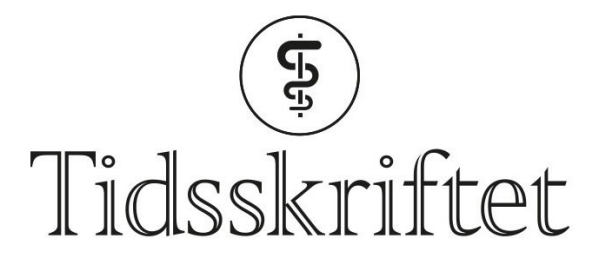

DEN NORSKE LEGEFORENING

\title{
Lovende, men langt frem for ny osteoporosemedisin
}

FRA ANDRE TIDSSKRIFTER

ØYVIND STOPLE SIVERTSEN

Tidsskriftet

Det monoklonale antistoffet romosozumab gir økt bentetthet hos postmenopausale kvinner med osteoporose.

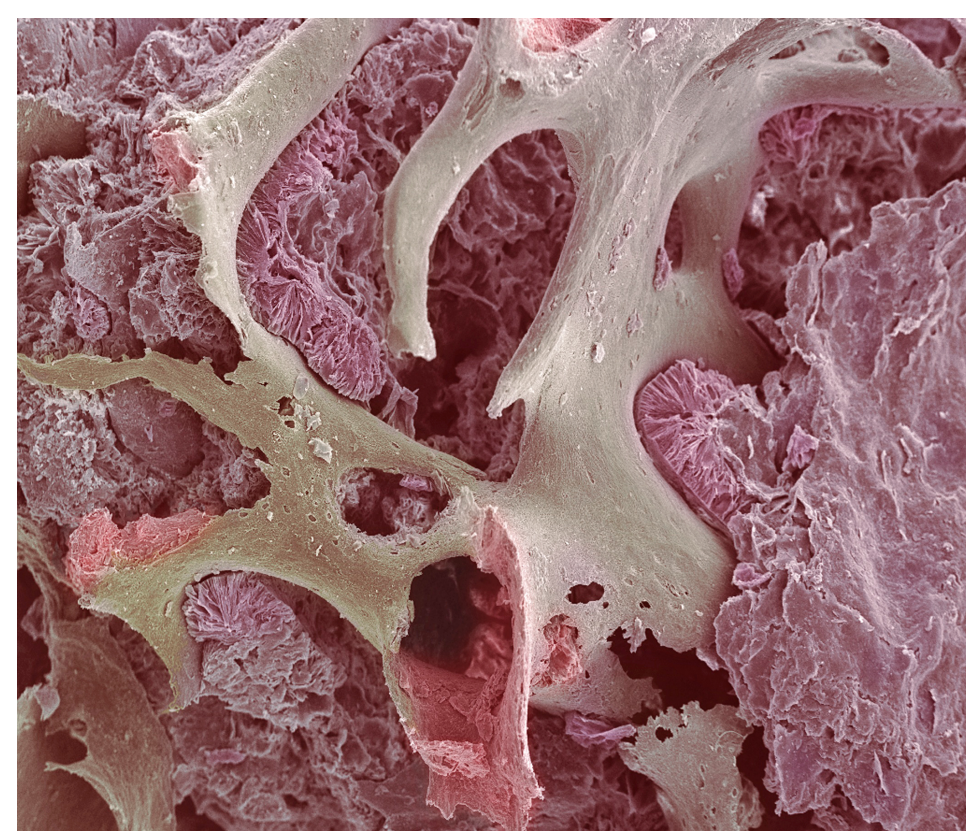

Osteoporotisk benvev. Illustrasjonsfoto: Science Photo Library/NTB scanpix

Førstevalget ved osteoporose er behandling med bisfosfonater. Ved behandlingssvikt, definert som to brudd under pågående behandling, vil man ofte bytte til anabol terapi med en parathyreoideahormon (PTH)-analog.

I en randomisert, åpen studie som nylig er publisert i The Lancet, ble effekten av et nytt anabolt preparat, romosozumab, sammenlignet med PTH-analogen teriparatid hos om lag 400 postmenopausale kvinner som allerede ble behandlet med et bisfosfonat (1). Romosozumab er et monoklonalt antistoff som kan binde seg til sclerostin, et protein som skilles ut av osteocytter og som hindrer bendanning. Etter 12 måneder var bentettheten $\emptyset \mathrm{kt}$ med 2,6\% blant dem som fikk romosozumab, men redusert med o,6\% hos dem som fikk teriparatid. Forekomsten av bivirkninger var omtrent like stor.

- Denne studien viser at behandling med romosozumab gir økt bentetthet hos 
postmenopausale kvinner med osteoporose, men studien er for liten og oppfølgingstiden for kort til å si om dette også gir lavere bruddrisiko, som jo er det som er klinisk relevant, sier Guri Grimnes, overlege ved Endokrinologisk seksjon, Universitetssykehuset NordNorge og førsteamanuensis ved Universitetet i Troms $\emptyset$ - Norges arktiske universitet.

- Det er åpenbart at vi trenger mer kunnskap for å optimalisere og individualisere behandlingen for pasienter med osteoporose, sier Grimnes.

Hun påpeker at en større, nylig publisert studie viste flere kardiovaskulære hendelser ved bruk av romosozumab enn med bruk av alendronat (2). - Det er således langt frem og behov for flere studier før vi kjenner romosozumabs plass i behandlingen for osteoporose, sier hun.

\section{LITTERATUR:}

1. Langdahl BL, Libanati C, Crittenden DB et al. Romosozumab (sclerostin monoclonal antibody) versus teriparatide in postmenopausal women with osteoporosis transitioning from oral bisphosphonate therapy: a randomised, open-label, phase 3 trial. Lancet 2017; 390: 1585 - 94. [PubMed][CrossRef]

2. Saag KG, Petersen J, Brandi ML et al. Romosozumab or alendronate for fracture prevention in women with osteoporosis. N Engl J Med 2017; 377:1417 - 27. [PubMed][CrossRef]

Publisert: 8. januar 2018. Tidsskr Nor Legeforen. DOI:10.4045/tidsskr.17.0998

(C) Tidsskrift for Den norske legeforening 2020. Lastet ned fra tidsskriftet.no 